\title{
WUJUD BUDAYA DALAM NOVEL TEGUH ANAK JADAH KARYA A.D. DONGGO (KAJIAN ANTROPOLOGI SASTRA)
}

\author{
Amiruddin \\ SMAN 1 Tumijajar, Tulang Bawang Barat, Lampung \\ Handphone 0858-5222-2007; Email kangmasbq@gmail.com
}

\begin{abstract}
Abstrak: Penelitian ini berorientasi pada wujud budaya dalam novel Teguh Anak Jadah Karya A.D. Donggo yang diteliti dari tinjauan antropologi sastra. Interdisiplin ilmu antara antropologi dan sastra memberikan pemahaman baru terhadap gejala kebudayaan manusia dalam karya sastra. Adapun metode yang digunakan dalam penelitian ini menggunakan metode hermeneutika. Metode ini memahami teks yang diuraikan dan diperuntukkan bagi penelaahan teks karya sastra. Hermenetik cocok untuk membaca karya sastra karena dalam kajian sastra, apa pun bentuknya, berkaitan dengan suatu aktivitas yakni interpretasi. Secara umum penelitian ini menemukan wujud budaya dalam novel Teguh Anak Jadah Karya A.D. Donggo. Wujud budaya berupa sistem nilai, sistem norma, kebudayaan fisik, aturan-aturan khusus, aktifitas kebudayaan berpolitik, dan hasil karya. Novel Teguh Anak Jadah Karya A.D. Donggo ini juga menampilkan dampak kekuasaan rezim orde baru beserta kroninya yang membuat pola pikir masyarakat saat itu menjadi tertekan, kebiasaan bungkam tertanam dalam-dalam selama pemerintahan orde baru telah menimbulkan kebiasaan baru yang mudah lupa. Melupakan peranan diri sendiri, peranan organisasi, peranan keluarga, dalam melawan sesama warga negara yang berbeda ideologi.
\end{abstract}

Kata kunci: wujud budaya, perlawanan, kekuasaan

\begin{abstract}
This research-oriented culture and a form of resistance against the culture of power in the novel Teguh Anak Jadah by A.D. Donggo studied from anthropological literature review. Interdisciplinary between anthropology and literature provide new understanding of the phenomenon of human culture in literature. The method used in this study using hermeneutic methods. This method outlined understand the text and the text intended for a review of literature. Hermeneutical suitable for reading literature for the study of literature, whatever its form, related to an activity that interpretation. In general, the study found a form of culture and a form of resistance against the culture of power in the novel Teguh Anak Jadah by A.D. Donggo. Cultural manifestation in the form of a value system, a system of norms, physical culture, specific rules, politics cultural activities, and the work. Novel Teguh Anak Jadah by A.D. Donggo It also shows the impact of the New Order regime and its cronies make public mindset when it becomes depressed, silent habit deeply ingrained during the New Order government has given rise to a new habit that is easy to forget. Forgetting the role of self, the role of the organization, the role of the family, against fellow citizens of different ideologies.
\end{abstract}

Keywords: form of culture, resistance, power 


\section{PENDAHULUAN}

Novel Teguh Anak Jadah karya A.D. Donggo merefleksikan kehidupan manusia di bawah tekanan kekuasaan yang semakin menyusahkan rakyat, berbagai perlawanan dilakukan oleh para pemuda yang dalam hal ini didominasi oleh para mahasiswa yang menuntut berhentinya kekuasaan yang dianggap diktator. Dengan jiwa muda yang ia miliki segala harapan masyarakat luas ia berangkat membawa misi tersebut demi kesejahteraan bersama yaitu dengan melakukan demonstrasi untuk melengserkan kekuasaan rezim yang dianggap diktator dan otoriter.

Budaya modern atau lebih umumnya disebut budaya pop menduduki posisi terkini dalam kehidupan bermasyarakat, kelangsungan hidup didasarkan pada cara berpikir yang memengaruhi kebudayaan yang mulai muncul. Di dalam novel Teguh Anak Jadah karya A.D. Donggo ini kebudayaan modern ditunjukkan oleh setiap tokoh yang ada dalam novel tersebut melakukan sebuah perlawanan terhadap kekuasaan otoriter yang dilakukan oleh rezim dan para pengikunya, dalam hal ini mahasisiwa yang menjadi penggerak penolakan tersebut. Kekuasaan yang dilakukan oleh rezim beserta para pengikutnya menjadi sebuah budaya kelompok kelas atas dengan kelompok kelas bawah, kelompok kelas atas cenderung memiliki kekuasaan penuh dalam segala hal, dan ini menyebabkan kelompok kelas bawah menjadi termarginalkan status dan hak miliknya, meskipun sebagian besar hasil dari kelompok kelas atas namun ketidaksetaraan harkat dan martabat menjadi pemicu sebuah perlawanan.

Keberadaan dan kemunculan pemuda menjadi pokok terealisasikannya sebuah harapan para orang tua dalam melangsungkan perlawanan terhadap sistem pemerintahan yang otoriter. Gerakan reformasi yang dilancarkan oleh pemuda dalam hal ini dilakukan mahasiswa dan masyarakat Indonesia pada penghujung abad 20 telah menjadi catatan sejarah bangsa. Salah satu titik kulminasi gerakan reformasi adalah turunnya Soeharto dari singgasana kepresidenan yang telah didudukinya selama tidak kurang dari 30 tahun. Selama rentang waktu tersebut, masyarakat Indonesia "dibius" untuk menganggap jabatan presiden sebagai suatu hal yang mahal dan sakral, hanya Soeharto yang bisa. Rezim yang berkuasa tidak pernah memberi ruang kontestasi bagi manusia-manusia Indonesia untuk unjuk gigi, bila pun ada yang mempertanyakan atau ada tokoh yang mencoba mencalonkan diri dianggap sebagai tindakan subversif, perilaku dosa terhadap negara. Tidak mengherankan bila masyarakat mengenang peristiwa Mei 1998 sebagai satu langkah sejarah bangsa yang maha penting. Peristiwa yang telah menebus kemustahilan dan juga sebuah keberhasilan dari banyak kegagalan pada masa lalu. Mungkin anggapan serupa tidak saja terlontar dari masyarakat Indonesia sendiri, namun masyarakat internasional.

Novel Teguh Anak Jadah karya AD. Donggo bercerita tentang seorang aktivis mahasiswa yang lahir dari rahim pelacur, Ratih. Sejak kecil Teguh hanya diasuh oleh ibunya. Itu sudah jadi resiko profesi ibunya, yang menjual senyum dan kemolekan tubuhnya. Dengan susah payah dan atas kegigihannya Ratih membesarkan Teguh di kampung halamannya. Hingga Teguh dapat mengenyam pendidikan dari bangku sekolah sampai kuliah. Dan dia tumbuh menjadi anak yang cerdas dan tangkas.

Semasa menjadi mahasiswa Teguh aktif dalam dunia pergerakan, tak ayal dia menjadi sosok demonstran yang lantang 
dan disegani oleh kawan-kawannya. Seringkali Teguh terlibat dalam demonstrasi yang menggugat Soeharto agar ditarik ke meja hijau untuk mempertanggung-jawabkan perilakunya; yang disinyalir banyak melakukan perbuatan yang berlawanan dan melanggar HAM, serta mementingkan diri sendiri, keluarga, serta kronikroninya di atas kepentingan masyarakat.

Konflik mulai terjadi saat dirinya diundang makan malam oleh Tuan Harso Widagdo, ayah Rini, yang merupakan seorang tokoh pendukung setia mantan rezim orde baru. Rini adalah kawan kuliah Teguh, yang juga sama-sama terlibat dalam demonstrasi. Dalam acara makan malam bersama itu Tuan Harso Widagdo mencoba membujuk Teguh agar tidak lagi menggugat dan menghujat rezim yang dibelanya. Bila Teguh sepakat dengan permintaannya, Harso Widagdo berjanji akan membiayai seluruh keperluan perkuliahannya. Teguh menolaknya. Peristiwa tersebut membuat hubungan Rini dengan Teguh menjadi kaku. Bahkan Teguh mulai beranggapan keikutsertaan Rini dalam demonstrasi sebatas strategi yang dilakukan Harso Widagdo untuk dijadikan mata-matanya. Rini tidak terima atas tuduhan yang dilontarkan Teguh. Butuh waktu yang lama untuk Rini dapat meyakinkan Teguh dan kawan-kawannya, bahwa dirinya berbeda haluan dengan ayahnya. Hubungan kembali mencair.

Tema novel yang ditulis oleh sastrawan yang pernah dikenai popor senapan oleh penjajah Belanda ini terbilang menarik, dan pembaca dapat merasakan nuansa nostalgia perjuangan aktivis yang gigih memperjuangkan nilainilai demokrasi di negeri ini. Pada masa sekarang, mungkin, belum banyak sastrawan yang mengangkat tema seputar politik ke dalam perwajahan novel. Terlebih bila pembacanya adalah (mantan) aktivis demonstran yang mengalami dan terlibat langsung dengan peristiwa demonstrasi saat orde baru masih berkuasa. Membaca novel ini dapat menjadi sarana mengantarkannya pada pengalamannya dulu, seolah-olah setting tokoh novel adalah dirinya sendiri yang penuh heroik dan suasana yang tragik.

Membaca karya ini seakan diajak untuk ziarah kenangan ke dunia lika-liku perjuangan dan tantangan saat itu; penculikan, pembunuhan, penjara, serta bakti diri terhadap orang tua. Diakui atau tidak, aktivis 98 banyak yang berangkat dari keluarga-keluarga yang dekat, akrab, dan pemuja rezim Soeharto. Pertentangan antara orang tua dan anak seringkali terjadi.

Tema yang apik, namun disampaibahasakan kaku dan kurang menarik. Seakan Donggo terjebak pada besaran tema yang diangkat, tanpa dibungkus dengan gaya tuturan sastrawi yang renyah, indah, dan enak dibaca. Kekuatan kata-kata yang dramatik tidak terlihat di dalamnya. Bukankah dalam karya sastra kekuatan kata-kata adalah yang utama, di mana dimaksudkan dapat menghidupkan suasana yang sedang terjadi dan dibangunnya. Seperti yang ditulis Jakob Soemardjo (2004), bukankah tugas seorang sastrawan bukan "bercerita" belaka, tetapi menghidupkan ceritanya seperti aktor bermain di panggung. Untaian kata-kata dalam karya sastra tidak sebatas bercerita tentang yang terjadi, tapi lebih dari itu, menghidupkan sehingga pembaca seakan mengalaminya (imajinasi). Juga tanpa harus terjebak pada karya sastra sebatas komoditashiburan yang melenakan, pesan yang tertanam tidak tergali.

\section{METODE PENELITIAN}

Pendekatan yang dilakukan menggunakan metode deskriptif analisis. 
Metode deskriptif analisis dilakukan dengan cara mendiskripsikan fakta-fakta yang kemudian disusul dengan analisis (Ratna, 2103:53). Deskripsi yang dimaksudkan dilanjutkan dengan analisis sehingga pada akhirnya menghasilkan suatu kesimpulan. Sebagai model penelitian interdisiplin dalam antropologi sastra disarankan untuk mencoba menemukan teori dari bawah, sebagaai teori grounded (Ratna, 2011:256).

Metode yang digunakan dalam penelitian ini adalah menggunakan studi pustaka, kelebihan studi pustaka adalah sifat objek materialnya yang relative tetap sehingga penelitian dapat dilakukan secara berulang-ulang (Ratna, 2011:255). Dengan kalimat lain bahasa, dalam hubungan ini bahasa tulis sebagai objek material tidak berubah, bahkan sepanjang masa.

Antropologi sastra termasuk upaya untuk menggali sejumlah pengalaman budaya melalui langkah-langkah yang matang. Langkah-langkah selalu dikaitkan oleh proses refleksi. Oleh karena asumsi yang dibangun antropologi sastra, karya itu merupakan sebuah cermin budaya. Sastrawan menjadi pemotret budaya yang beragam. Potret itu menjadi sebuah tiruan yang simbolis.

Adapun objek material dalam penelitian ini adalah karya sastra dengan genre prosa, Novel Teguh Anak Jadah Karya A.D. Donggo yang dimaksud memberikan peluang untuk diteliti dari sudut pandang studi pustaka dengan tinjauan antropologi sastra, sehingga hasil yang diharapkan adalah mengetahui unsur antropologi dari sastra bukan antropologi dalam sastra.

\section{HASIL PENELITIAN DAN PEMBAHASAN}

Pada bagian ini disajikan hasil penelitian dan pembahasan. Hasil penelitian dan pembahasan ini didasarkan pada temuan penelitian yang berfokus pada a) Wujud budaya sebagai ide, b) Wujud budaya sebagai norma, c) Wujud budaya sebagai nilai, d) Wujud budaya sebagai sistem sosial, e) Wujud budaya sebagai hasil karya dalam novel Teguh Anak Jadah karya A.D. Donggo.

\section{Wujud Budaya Sebagai Ide}

Ide dan gagasan dikaitkan dengan pola pikir yang tercipta dari masingmasing kelompok masyarakat yang melakukan eksplorasi untuk kelangsungan hidup, dalam hal ini masyarakat memiliki adat istiadat tertentu. Kaitannya dalam budaya modern dalam novel ini, Donggo berbicara melalui karyanya menyuarakan ketimpangan dari pemerintahan zaman orde baru yang dikenal otoriter. Melalui tokoh Teguh, Donggo yang juga pernah menjadi salah satu anggota demonstrasi yang ikut andil dalam menuntut dilengserkannya pemerintah zaman Soeharto, karena dinilai pemerintahan Indonesia saat itu tidak membuat rakyat merasa aman dan nyaman.

Keinginan untuk bertahan hidup ditengah-tengah minimnya lahan pekerjaan yang menyebabkan banyaknya pengangguran yang tak dapat ditolak, banyak anak kecil yang semestinya mendapatkan bimbingan belajar di kelas harus diganti menjadi pengamen jalanan, banyak perempuan yang dengan bekal seadanya rela bekerja untuk mempertahankan hidup sebagai buruh, bahkan sebagai penghibur para lelaki hidung belang. Dengan demikian, ideologi tidak dapat dilihat sebagai dominasi sederhana namun harus dilihat sebagai diskursus yang mengandung konsekuensi spesifik terhadap relasi kekuasaan pada semua level hubungan sosial (Barker, 2015:68). Keinginan untuk menjual diri bukanlah sebuah keinginan atau sama-sama melepas nafsu 
manusiawinya, justru dengan melakukan pekerjaan demikian para perempuan merasa mendapatkan pekerjaan meskipun mereka juga tahu bahwa pekerjaan demikian melanggar hukum Negara dan agama.

Namun tidak pernah dikatakan, bahwa sang suami punya bakat untuk melacur. Punya bakat untuk berzina. Walau si laki-laki atau si suami mengetahui bahwa zina itu dosa, dan dikutuk oleh Tuhan dan agama. (Donggo, 2005:21)

Selama ini, pelacuran selalu dikaitkan oleh perempuan, seakan perempuan adalah pusat segala perbuatan kekejian yang mendapar cercaan dari banyak pihak, dalam hal ini posisi seorang laki-laki seakan-akan tetap suci, tak sempat mendapatkan jatah dosa atau hukuman untuk kejelekan dalam hal pergaulan.

Dalam novelnya, Donggo mengungkapkan bentukan rezim itu berhasil membentuk karakter yang memposisikan derajat laki-laki lebih dominan dari perempuan, segala kegiatan dan pekerjaan didominasi oleh laki-laki. Laki-laki menduduki posisi yang utama. Sehingga dalam melakukan perbuatan yang tidak baik pun seorang laki-laki dianggap masih memiliki keunggulan tersendiri.

Sebuah pertanyaan lain yang cukup aneh kedengarannya. Kenapa tidak. Karena selama ini yang selalu dikatakan pelacur adalah perempuan, sedang laki-laki tetap akan masuk surga. (Donggo, 2005:21)

Kekuatan dan kekuaasaan dimiliki oleh seorang laki-laki, segala keinginannya menjadi keinginan pula seorang perempuan, perempuan hanya ikut di belakang, peran perempuan jauh lebih tertinggal dibandingkan dengan laki-laki. Apapun kehendak seorang lakilaki harus dituruti oleh seorang perempuan. Fakta bahwa kekuasaan menyebar, atau bahwa komoditas secara subversive digunakan untuk menghasilkan suatu identitas baru (Barker, 2015:126).

Pemerintahan zaman orde baru telah membuat pola pikir rakyat menjadi praktis, segala problem yang muncul bisa diatasi dengan uang, uang telah menjadi alat yang sangat berharga dalam mengatasi masalah, meskipun dampak dari mengedepankan uang dapat menyebabkan keberanian untuk mendapatkan uang walaupun dengan berbagai cara yang tidak sewajarnya misalkan, mencuri, merampok, atau lebih sopannya lagi dengan cara berutang.

Rezim itu mungkin menyimpulkan untuk membangun kemakmuran Indonesia harus dengan utang. Tapi apa yang terjadi? Indonesia tidak tambah makmur malah ekonomi Indonesia makin terpuruk. (Donggo, 2005:105)

\section{Wujud Budaya Sebagai Norma}

Dalam menjaga kelangsungan kehidupannya, manusia tidak hanya berusaha untuk mengontrol alam sekitar tetapi juga perlu untuk mengontrol dirinya dan masyarakat itu sendiri. Alam sekitar tidak akan dapat dikuasai apabila masyarakat tidak dapat dikontrol secara normatif. Manusia dan masyarakat bila tidak mampu mengontrol dirinya secara normatif maka kelangsungan kehidupannya tidak dapat terjamin.

Dalam kesehariannya manusia terikat oleh tata aturan yang dalam hal ini mempunyai tujuan mengatur semua aspek kehidupan manusia di dalamnya, aturan kemanusiaan dibuat untuk mengatur selayaknya manusia hidup sesuai peran yang dimilikinya, kesadaran menjaga harga diri menjadi tanggung jawab bersama. 
Dengan menjalin hubungan dengan Ratih, terkadang Badri tercenung, misalnya, kalau dia tidak menemukan kebahagiaan di rumah, kenapa harus terjerumus ke dalam pencarian kesenangan sesaat dengan pelacur?. (Donggo, 2005:27)

Sebuah rumah tangga yang dijalin bersama keluarganya tidak harus selalu merasakan kebahagiaan dan kepuasaan hidup, dibalik semua harapan itu tidak kemudian selalu merasakan kebahagiaan yang berkepanjangan. Masalah-demi masalah menjadi bumbu dalam rumah tangga.

Ada dua pilihan dalam mengarungi bahtera rumah tangga, menikmati kebahagiaan dan bersabar dalam menghadapi masalah, karena lain orang lain pula cara menghadapi masalah. Seperti yang dilakukan Badri sebagai pelarian kekecewaan dalam kehidupan rumah tangganya, ia tidak jarang mengunjungi rumah bordil itu hanya untuk sekadar menghibur diri, selebihnya sangat mungkin untuk melepaskan beban hidupnya kepada orang yang bisa memahami dan menerima curahan hatinya.

Bagi Badri sendiri seperti selalu dikeluhkannya kepada Ratih kalau mereka bertemu, dia tidak memperoleh kebahagiaan di rumah. Terutama sebagai laki-laki dan sebagai suami. Padahal sebelum kawin dengan Sari, sang istri, mereka saling mencintai. (Donggo, 2005:22)

Sebuah hubungan antar manusia yang menjadikan keakraban memang menjadi salah satu tujuan setiap orang untuk saling mencurahkan isi hati, namun dibalik semua itu ciri bangsa timur adalah merasa rendah dihadapan orang lain terlebih kepada orang yang baru dikenalnya, Ratih yang merasa dirinya tidak pantas berhubungan dengan orang yang baru saja ia kenal.
Tanpa ragu Harjana menyapa Ratih kemudian menawarkan singgah di sebuah warung untuk minum. Ratih agak kaget terhadap tawaran itu. Karena itu dia berusaha menolaknya secara halus. Dia merasa tidak pantas menemani guru itu. Terutama karena tiba-tiba rasa rendah diri sebagai bekas pelacur serentak menguasai perasaan dan pikirannya. (Donggo, 2005:34)

Sejak hubungan antar sesama manusia terjalin, keinginan untuk lebih mengenal lebih jauh pasti menjadi salah satu ciri setiap orang dalam berinterkasi, budaya timur mengajarkan perasaan menghormati orang lain dalam hal kepentingan, mendahulukan orang lain dari pada diri sendiri. Cara seperti itu telah dimiliki oleh orang jawa.

\section{Wujud Budaya Sebagai Nilai}

Sistem nilai budaya merupakan rangkaian dari konsep-konsep abstrak yang hidup dalam masyarakat, mengenai apa yang dianggap penting dan berharga, tetapi juga mengenai apa yang dianggap remeh dan tidak berharga dalam hidup. Sistem nilai budaya ini menjadi pedoman dan pendorong perilaku manusia dalam hidup yang memanifestasi kongkritnya terlihat dalam tata kelakuan. Dari sistem nilai budaya termasuk norma dan sikap yang dalam bentuk abstrak tercermin dalam cara berfikir dan dalam bentuk konkrit terlihat dalam bentuk pola perilaku anggota-anggota suatu masyarakat.

Nilai budaya mengalami pergeseran disebabkan cara berpikir yang sesuka hati, tanpa berpikir bahwa yang dilakukan memiliki dampak negatif bagi masyarakat yang lain, akan tetapi sifat egois dan ingin menang sendiri untuk meraih kekuasaan tidak memandang baik dan buruk.

Dan selama tiga puluh tahun pula meninggalkan bom waktu yang berwujud kesenjangan sosial. Hanya 
kroni dan orang-orang dekat dengan kekuasaan yang dengan leluasa membangun kekayaan pribadi dengan segala cara. Halal atau haram. Hal. 234

Kedudukan nilai dalam setiap kebudayaan sangatlah penting, maka pemahaman tentang sistem nilai budaya dan orientasi nilai budaya sangat penting dalam konteks pemahaman perilaku suatu masyarakat dan sistem pendidikan yang digunakan untuk menyampaikan sistem perilaku dan produk budaya yang dijiwai oleh sistem nilai masyarakat yang bersangkutan.

Dalam kaitannya budaya modern, yang dalam hal ini seperti gambaran yang ditulis Donggo memperlihatkan kerendahan moral yang dimiliki pemerintah zaman orde baru saat itu yang berusaha untuk lari dari tanggung jawab sebagai pemegang kemudi pemerintahan, secara apatis pemerintah saat itu menggunakan kekuatannya untuk menghilangkan jejak kelicikannya, sebagaimana dalam kutipan dibawah ini:

\footnotetext{
"bukan," bantah Teguh. "Rezim itu secara pengecut memecat dirinya sendiri sebagai presiden, karena melihat ekonomi mulai ambruk. Secara licik dia mau cuci tangan, melepas tanggung jawab." Hal. 237
}

Rakyat sebagai kelompok masyarakat selalu memperhatikan dan menyimak apa yang dilakukan para pemimpinnya bahkan bissajuga meniru cara menjadi pemimpin yang yang dpaat memperkaya diri dan keluarga beserta teman-teman kerja, untuk menumpuk kekayaan meskipun dengan cara yang bertentangan dengan nilai kemanusiaan bahkan agama, karena bagi mereka hukum Negara yang berlaku dapat dibeli dengan uang.

Nilai-nilai kemanusiaan dijunjung tinggi oleh leluhur bangsa Indonesia untuk menciptakan keluhuran jati diri sebagai bangsa yang merdeka dan berkuasa menentukan cara pandang dan pola berpikir yang lebih maju, dalam kaitannya untuk menjaga nilai tersebut dalam novel ini Donggo mengungkapkan melalui kutipan percakapan antara Tuan Harso dan Teguh, percakapan ini berlangsung ketika Tuan Harso sedang berkunjung ke tempat Teguh,

\section{Wujud Budaya Sebagai Sistem Sosial}

Masyarakat mempunyai bentukbentuk struktural, yang dinamakan struktur sosial. Struktur sosial ini bersifat statis dan bentuk dinamika masyarakat disebut proses sosial dan perubahanperubahan sosial. Masyarakat yang mempunyai bentuk-bentuk strukturalnya tentu mengalami pola-pola perilaku yang berbeda-beda juga tergantung dengan situasi yang dihadapi masyarakat tersebut. Perubahan dan perkembangan masyarakat yang mengarah pada suatu dinamika sosial bermula dari masyarakat tersebut melakukan suatu komunikasi dengan masyarakat lain, mereka membina hubungan baik itu berupa perorangan atau kelompok sosial. Tetapi sebelum suatu hubungan dapat terjadi perlu adanya suatu proses berkaitan dengan nilai-nilai sosial dan budaya dalam masyarakat. Dengan suatu masyarakat yang mengetahui nilai sosial dan budaya masyarakat lain maka hubungan dapat terbentuk. Maka dapat diartikan bahwa proses sosial adalah sebagai pengaruh timbal balik antara berbagai segi kehidupan bersama.

Karena rezim itu masih punya kekuatan, terutama kekuatan uang, juga militer. Termasuk Ayah sendiri. Dengan kekuatan uang, Ayah mencoba menyogok Teguh dengan menawarkan menanggung biaya kuliahnya. (Donggo, 2005:178)

Pada kutipan di atas dapat diketahui, bahwa cara bernegara mereka gunakan sebagai cara pelan-pelan dengan 
mengukur sesuatu dengan cara pemberian materi, mereka menganggap dengan cara politik uang mereka akan berkuasa dan lupa dari mana dan dengan cara bagaimana mereka dapatkan.

Kerendahan harga diri kemanusiaan telah terlihat dengan jelas, hal ini didominansi adanya saling curiga, ketakutan telah menjadi mindset masyarakat modern setelah kekuasaan rezim orde baru memegang peran penting di Negara ini.

Dalam kaitannya dengan perlawanan, sebagai anak panah sebuah perjuangan didukung kuat oleh suara para mahasiswa, Teguh sebagai peran utama dalam novel ini tengah melangsungkan perlawanan dengan cara demonstrasi.

Tapi karena kecongkakannya, dia mengatakan Teguh anak seorang pelacur. Sekarang anak perempuan pelacur itu adalah salah seorang anak yang berani melawan kekuasaan rezim sekarang. (Donggo, 2005:107)

Keinginan untuk mempertahankan hidup seperti yang dilakukan oleh Ratih menjadi fokus terpenting dalam kaitannya bersosialisasi, kesadaran untuk memperoleh kesamaan derajat, harkat dan martabat. Bagi Ratih pelacur tetap perlu dilakukan meskipun ia sendiri hal demikian melanggar aturan agama dan Negara.

Merantau adalah cara kebanyakan yang dilakukan oleh setiap orang untuk mengubah hidupnya lebih baik dari sebelumnya, banyak hal yang ingin dilakukan dalam perantauan namun dalam rangka mengubah tingkat sosial yang lebih mapan hal ini kerap menjadi tujuan akhir bagi yang perantau kebanyakan.

Selama merantau Ratih yang dulu pernah menjadi salah satu pelacur di rumah bordil itu ketika pulang ke desanya, ia ingin ke Jakarta lagi untuk mencari orang yang dulu pernah menghamilinya, bagaimana mungkin ini dapat dilakukan karena seorang pelacur tidak mungkin bergaul denga satu orang saja, namun hal ini tidak bagi Ratih karena ia mengakui bahwa dengan seorang laki-laki itulah ia hamil dan setelah itu ia tidak pernah melakukan hubungan dengan laki-laki mana pun.

Dan aku datang lagi ke Jakarta menjumpai kau hanya ingin memastikan apakah bentuk wajah anak ini benar menjiplak bentuk wajahmu. Dan memang benar, seperti kau lihat. (Donggo, 2005:15)

Sejak saat Ratih di Jakarta ia ingin mengubah nasib hidupnya dengan bekerja sebagai pembantu rumah tangga, namun ia lebih dulu ditipu oleh orang yang menawarkan pekerjaan yang baik untuk Ratih dan akhirnya Ratih dimasukkan ke dalam rumah bordil itu yang notabene tempat itu adalah tempat pelacuran.

\section{Wujud Budaya Sebagai Hasil Karya}

Hasil karya dalam sebuah kebudayaan selalau dikaitkan dengan benda-benda klasik, hal ini mungkin saja tercipta karena masyarakat saat itu masih berkutat pada nilai budaya yang sangat kental dengan ciri kedaerahan, beda dengan budaya modern seperti yang terdapat novel Teguh Anak Jadah. Segala aspek kehidupan tercermin adanya pembangunan yang biaya pembangunan tersebut dengan melipatkan cuci tangan terlebih dahulu sehingga pemerintah itu mendapat sebutan Bapak Pembangunan.

Karena rezim itu masih punya kekuatan, terutama kekuatan uang, juga militer. Termasuk Ayah sendiri. Dengan kekuatan uang, Ayah mencoba menyogok Teguh dengan menawarkan menanggung biaya kuliahnya. (Donggo, 2005:178)

Kekuatan kekayaan menjadi alat penebus hukum apabila di antara mereka 
melakukan sebuah kelalaian atau masalah yang bertentangan dengan aturan pemerintahan, kebanyakan masyarakat tidak mampu hal demikian disebabkan masyarakat sendiri mengalami krisis yang berkepanjangan dan betul-betul menghambat perkembangan dalam urusan finansial, akibat lain adalah budaya takut dan malu, sehingga masyarakat lebih sering lupa, bahwa yang dilakukan adalah ketakutan dalam perlawanan.

... supaya bekas pemimpin rezim itu yang dia bela diseret ke pengadilan, sebuah pengadilan rakyat yang menuntut pertanggungjawaban atas seluruh perbuatannya yang membuat ekonomi menjadi berantakan. (Donggo, 2005:176)

Harapan tetap lah menjadi harapan kosong, kebanyakan mereka memiliki senjata dalam urusan keuangan. Apapun saja yang harus diculik, nyata benar kejadian itu membuat masyarakat ketakutan dan pengharapan mereka menjadi sebatas mimpi karena kemiskinan selalu membayang dihadapan mereka. Masyarakat setiap hari selalu dibayangi oleh keadaan yang mengkhawatirkan, kehidupan zaman orde baru dinilai tak ubahnya zaman penjajahan yang sama persis membuat kekhawatiran dan ketakutan tiada henti.

Zaman orde baru memang dikenal hasilnya yang luar biasa dalam bidang pembangunan, upaya membuat Indonesia semakin mentereng sangat tampak sekali, dalam berbagai sektor tampak megah namun tidak melihat bagaimana kondisi masyarakat golongan bawah khususnya masyarakat kecil yang sangat kesulitan dalam hal ekonomi.

"Kerusuhan yang terjadi diberbagai tempat, terutama masalah perut, itulah gambaran dari ketamakan rezim itu karena hanya memikirkan bagaimana memupuk kekayaan untuk dirinya sendiri, keluarga, kroninya dan antekanteknya, sedang bagi orang lain dan rakyat, persetan," tegas Rini. (Donggo, 2005:192)

Hasil karya dalam kebudayaan tidak selalu berupa benda-benda atau tempat klasik sebagai warisan leluhur, bukti sejarah yang pernah dibuat oleh orang-orang dalam kaitannya budaya modern tidak sama persis dengan kebuddayaan klasik, hal ini cukup tekenang dalam sejarah mengenai dampak kekuasaan yang otoriter dan diktator yang masih membuat luka yang termaafkan bagi bangsa ini selama tiga puluhan tahun yang berujung pada tahun 1998 sejak peralihan dari era orde lama menjadi orde baru.

Dan selama tiga puluh tahun pula meninggalkan bom waktu yang berwujud kesenjangan sosial. Hanya kroni dan orang-orang dekat dengan kekuasaan yang dengan leluasa membangun kekayaan pribadi dengan segala cara. Halal atau haram. (Donggo, 2005:234)

Nilai kemanusiaan tidak lagi menjadi bagian penting bagi jati diri bangsa, segala kepentingan dinilai dari materi, kekuatan yang menjadi dasar bagi orang-orang saat itu adalah kekuatan uang, kepandaian dan kelicikan menjadi pemicu mengubah bangsa ini menjadi bangsa yang lemah, yaitu membunuh dirinya sendiri melalui akarnya.

Penelitian yang dilakukan Raodah dalam melalui skripsinya yang berjudul Wujud Budaya Masyarakat Makassar dalam Ungkapan Mantra Pagalung: Tinjauan Antropologi Sastra. mengungkapkan dan menjelaskan tahapan pengolahan sawah secara tradisional, bentuk dan struktur pengungkapan mantra pagalung, serta wujud budaya masyarakat yang tercermin di dalam mantra pagalung di desa Bontomanai kecamatan Tompobulu 
kabupaten Maros. (Skripsi Universitas Hasanuddin Makassar.2015).

Dalam kaitannya bentuk kebudayaan suatu masyarakat terlihat melalui cara mereka mengatur tatanan sosial, penelitian ini memfokuskan hasil dari kekuasaan rezim orde baru yang diimplementasikan melalui karya sastra.

\section{SIMPULAN}

Wujud budaya sebagai hasil karya tidak selalu dikaitkan dengan bendabenda klasik yang sebagaimana banyak ditemukan dalam kajian pada umumnya. kebudayaan modern telah memberikan pengetahuan baru mengenai hasil dari masyarakat karena budaya dapat muncul sebab adanya masyarakat yang memiliki cara pandang dan cara berpikir sehingga mereka menciptakan seduah kebudayaan baru.

Sistem ide pada pemerintahan zaman orde baru telah membuat pola pikir rakyat menjadi praktis, segala problem yang muncul bisa diatasi dengan uang, meskipun dampak dari mengedepankan uang dapat menyebabkan keberanian untuk mendapatkan uang walaupun dengan berbagai cara yang tidak sewajarnya misalkan, mencuri, merampok, atau lebih sopannya lagi dengan cara berutang. Sistem norma dapat diketahui melalui keinginan mencari kesenangan dalam hidup berumah tangga memang menjadi tujuan setiap pribadi dalam keluarga. Sistem nilai kelompok masyarakat selalu memperhatikan dan menyimak apa yang dilakukan para pemimpinnya bahkan bisa juga meniru cara menjadi pemimpin yang memperkaya diri dan keluarga beserta teman-teman kerja, untuk menumpuk kekayaan meskipun dengan cara yang bertentangan dengan nilai kemanusiaan bahkan agama, karena bagi mereka hukum Negara yang berlaku dapat dibeli dengan uang. Sistem sosial mencerminkan kekuasaan yang dilakukan oleh rezim beserta para pengikutnya menjadi sebuah budaya kelompok kelas atas dengan kelompok kelas bawah, kelompok kelas atas cenderung memiliki kekuasaan penuh dalam segala hal, dan ini menyebabkan kelompok kelas bawah menjadi termarginalkan status dan hak miliknya.

\section{DAFTAR PUSTAKA}

Barker, Chris. 2004. Cultural Studies: Toeri dan Praktik. Yogyakarta. Kreasi Wacana.

Donggo, AD. 2005. Teguh Anak Jadah.Yogyakarta: Ombak.

Endraswara, Suwardi. 2013. Metodologi Penelitian Antropologi Sastra. Yogyakarta: Ombak.

Koentjaraningrat.1985. Kebudayaan Mentalitas dan Pembangunan. Jakarta: PT Gramedia.

Moleong, Lexy J. 2000. Metode Penelitian Kualitatif. Bandung: PT Remaja Rosdakarya.

Taum, Yoseph Yapi. 2015. Sastra dan Politik: Representasi Tragedi 1965 dalam Negara Orde Baru. Yogyakarta: Universitas Sanata Dharma.

Weber, Max. 2012. Teori Dasar Analisis Kebudayaan. Yogyakarta. IRCiSoD. 